\title{
Penerapan Metode Cooperative Learning untuk Meningkatkan Hasil Belajar Siswa pada Mata Pelajaran IPS Kelas 3 SDN Tambakrejo Gurah Kediri
}

Diterima:

11 Juni 2021

Revisi:

30 Juli 2021

Terbit:

1 Februari 2022

\author{
Putri Suci El Mahanani \\ Sekolah Dasar Negeri Tambakrejo \\ Kediri, Indonesia \\ E-mail: putrisucielmahanani@gmail.com
}

\begin{abstract}
Abstrak - Seorang guru seyogyanya harus mampu memilih model pembelajaran yang tepat bagi siswa. Penelitian terhadap siswa kelas 3 SDN Tambakrejo Gurah Kediri saat pembelajaran IPS bertujuan untuk mengetahui efektivitas metode cooperative learning untuk meningkatkan hasil belajar siswa pada mata pelajaran IPS dan gambaran hasil belajar siswa setelah dilaksanakan metode cooperative learning. Penelitian ini merupakan penelitian tindakan (action research), karena penelitian dilakukan untuk memecahkan masalah pembelajaran di kelas. Penelitian ini juga termasuk penelitian deskriptif, sebab menggambarkan bagaimana suatu teknik pembelajaran diterapkan dan bagaimana hasil yang diinginkan dapat dicapai. Berdasarkan hasil penelitian dan pembahasan diperoleh kesimpulan bahwa hasil belajar siswa kelas 3 SDN Tambakrejo Gurah Kediri cukup tinggi setelah diterapkan metode cooperative learning. Selain dapat meningkatkan minat belajar siswa, metode pembelajaran ini juga berhasil meningkatkan hasil belajar siswa. Hasil penelitian ini menunjukkan peningkatan hasil belajar yang cukup signifikan dari siklus I ke siklus II. Pada siklus I nilai rata-rata siswa dalam pemahaman materi adalah $66,45(58,06 \%)$, sedangkan pada siklus II mengalami peningkatan menjadi 80,64(83,87\%).
\end{abstract}

Kata Kunci- metode, cooperative learning, hasil belajar

Abstract - A teacher should be able to choose the right learning model for students. Research on grade 3 students at SDN Tambakrejo Gurah Kediri during social studies learning aims to determine the effectiveness of cooperative learning methods to improve student learning outcomes in social studies subjects and to describe student learning outcomes after implementing cooperative learning methods. This research is action research, because the research is conducted to solve learning problems in the classroom. This research also includes descriptive research, because it describes how a learning technique is applied and how the desired results can be achieved. Based on the results of the research and discussion, it was concluded that the learning outcomes of grade 3 students at SDN Tambakrejo Gurah Kediri were quite high after the cooperative learning method was applied. Besides being able to increase students' interest in learning, this learning method has also succeeded in improving student learning outcomes. The results of this study indicate a significant increase in learning outcomes from cycle I to cycle II. In the first cycle the average value of students in understanding the material was 66.45 (58.06\%), while in the second cycle it increased to 80.64 (83.87\%).

Keywords - methods, cooperative learning, learning outcomes 


\section{PENDAHULUAN}

Setiap proses belajar yang dilaksanakan oleh siswa akan menghasilkan hasil belajar. Di dalam proses pembelajaran, guru sebagai pengajar sekaligus pendidik memegang peranan dan tanggung jawab yang besar dalam rangka membantu meningkatkan keberhasilan peserta didik dipengaruhi oleh kualitas pengajaran dan faktor intern dari siswa itu sendiri. Dalam setiap mengikuti proses pembelajaran di sekolah sudah pasti setiap peserta didik mengharapkan mendapatkan hasil belajar yang baik, sebab hasil belajar yang baik dapat membantu peserta didik dalam mencapai tujuannya. Hasil belajar yang baik hanya dicapai melalui proses belajar yang baik pula. Jika proses belajar tidak optimal sangat sulit diharapkan terjadinya hasil belajar yang baik.

Guru di sekolah Dasar dalam mengajarkan pelajaran IPS tidak berarti mengajarkan disiplin ilmu-ilmu sosial, melainkan mengajarkan konsep-konsep esensi Ilmu Sosial untuk membentuk siswa menjadi warga Negara yang baik. Istilah Ilmu Pengetahuan Sosial (IPS) yang secara resmi mulai dipergunakan di Indonesia sejak tahun 1975 adalah istilah Indonesia untuk pengertian Social Studies. Dalam dunia pengetahuan kemasyarakatan atau pengetahuan sosial kita mengenal beberapa istilah seperti Ilmu Sosial, Studi Sosial, dan Ilmu Pengetahuan Sosial.

Berdasarkan pengamatan peneliti ditemukan bahwa dalam pembelajaran IPS di kelas 3 SDN Tambakrejo Gurah Kediri tentang memahami jenis pekerjaan dan penggunaan uang, siswa mengalami kesulitan dalam memahami jenis pekerjaan itu sendiri, yang mereka tahu terbatas hanya pada pekerjaan petani, guru, atau wira swasta. Karena mayoritas dari mereka orang tuanya berprofesi sebagai petani. Motivasi belajar siswa kurang, karena jenis pekerjaan yang mereka tau hanya terbatas pada masing-masing yang terlihat didaerah mereka tinggal.

Sebagai seorang guru harus mampu memilih model pembelajaran yang tepat bagi siswa. Karena itu dalam memilih model pembelajaran, guru harus memperhatikan keadaan atau kondisi siswa, bahan pelajaran serta sumber-sumber belajar yang ada agar penggunaan model pembelajara dapat diterapkan secara efektif dan menunjang keberhasilan belajar siswa. Oleh karena itu dalam penelitian ini peneliti memilih alternatif menggunakan metode pembelajaran kooperatif (cooperative learning) sebagai upaya langkah awal untuk menumbuhkan lingkungan belajar yang kondusif sekaligus untuk meningkatkan hasil belajar siswa dalam mata pelajaran Ilmu Pengetahuan Sosian (IPS). Metode pembelajaran kooperatif dapat digunakan pada semua mata pelajaran.

Model pembelajaran kooperatif adalah pembelajaran yang secara wajar dan sengaja mengembangkan, interaksi yang silih asuh untuk menghindari ketersinggungan dan kesalah pahaman yang dapat menimbulkan permusuhan. Pembelajaran kooperatif merupakan suatu 
PTK, Vol.2 No.2 2022

ISSN: 2747-1977 (Print) / 2747-1969 (Online)

DOI: https://doi.org/10.53624/ptk.v2i2.58

sistem yang didalamnya terkandung elemen-elemen yang saling terkait. Diantaranya: a) Saling ketergantungan positif, b) Interaksi tatap muka, c) Akuntabilitas individual, d) Keterampilan untuk menjalin hubungan antar pribadi atau ketrampilan sosial yang sengaja diajarkan. Singkatnya, pembelajaran kooperatif mengacu pada metode pembelajaran dimana siswa bekerja sama dalam kelompok kecil dan saling membantu dalam belajar. Pembelajaran kooperatif umumnya melibatkan kelompok yang terdiri dari 4 siswa dengan kemampuan yang berbeda dan ada pula yang menggunakan kelompok dengan ukuran yang berbeda-beda.

\section{METODE}

Penelitian ini merupakan penelitian tindakan (action research), karena penelitian dilakukan untuk memecahkan masalah pembelajaran di kelas. Penelitian ini juga termasuk penelitian deskriptif, sebab menggambarkan bagaimana suatu teknik pembelajaran diterapkan dan bagaimana hasil yang diinginkan dapat dicapai. Menurut Oja dan Sumarjan mengelompokkan penelitian tindakan menjadi empat macam yaitu, (a) guru sebagai penelitia; (b) penelitian tindakan kolaboratif; (c) simultan terintegratif; (d) administrasi social eksperimental (Titik Sugiarti 1997). Dalam penelitian tindakan ini menggunakan bentuk guru sebagai peneliti, penanggung jawab penuh penelitian ini adalah guru. Tujuan utama dari penelitian tindakan ini adalah untuk meningkatkan hasil pembelajaran di kelas dimana guru secara penuh terlibat dalam penelitian mulai dari perencanaan, tindakan, pengamatan, dan refleksi. Dalam penelitian ini peneliti tidak bekerjasama dengan siapapun, kehadiran peneliti sebagai guru di kelas sebagai pengajar tetap dan dilakukan seperti biasa, sehingga siswa tidak tahu kalau diteliti. Dengan cara ini diharapkan didapatkan data yang seobjektif mungkin demi kevalidan data yang diperlukan.

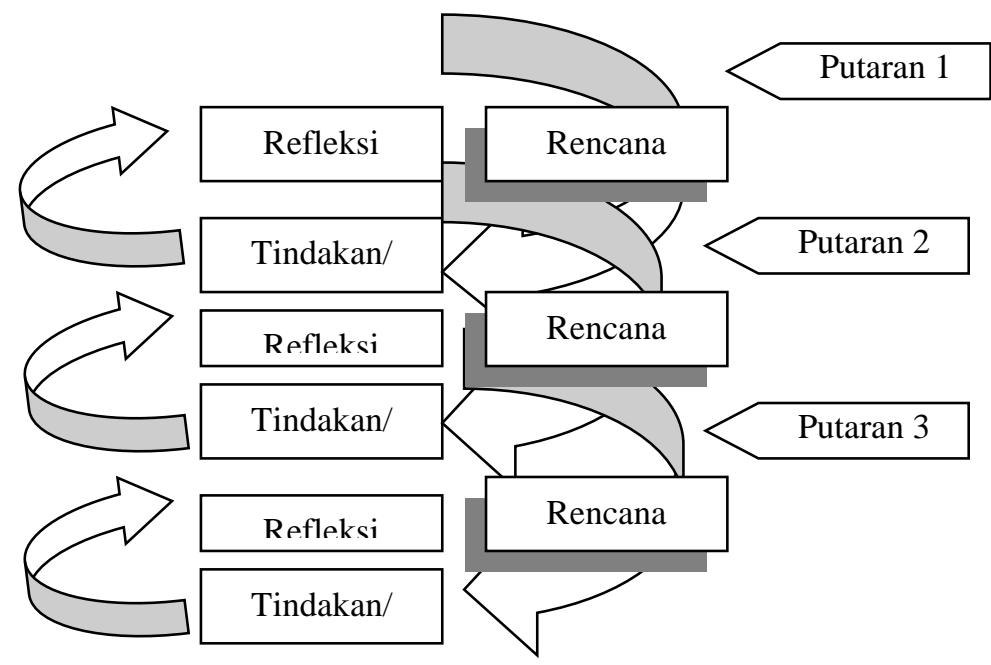

Gambar 1. Siklus Penelitian Tindakan Kelas. 
Penjelasan siklus di atas adalah:

1. Rancangan/rencana awal, sebelum mengadakan penelitian peneliti menyusun rumusan masalah, tujuan dan membuat rencana tindakan, termasuk di dalamnya instrumen penelitian dan perangkat pembelajaran.

2. Kegiatan dan pengamatan, meliputi tindakan yang dilakukan oleh peneliti sebagai upaya membangun pemahaman konsep siswa serta mengamati hasil atau dampak dari diterapkannya metode pembelajaran model kooperatif .

3. Refleksi, peneliti mengkaji, melihat dan mempertimbangkan hasil atau dampak dari tindakan yang dilakukan berdasarkan lembar pengamatan yang diisi oleh pengamat.

4. Rancangan/rencana yang direvisi, berdasarkan hasil refleksi dari pengamat membuat rancangan yang direvisi untuk dilaksanakan pada siklus berikutnya.

Subjek yang diteliti pada penelitian ini adalah siswa kelas III semester ganjil tahun ajaran 2019/2020 di SDN Tambakrejo Kecamatan Gurah Kabupaten Kediri dengan jumlah siswa sebanyak 31 siswa. Waktu penelitian adalah waktu berlangsungnya penelitian atau saat penelitian ini dilangsungkan. Penelitian ini dilaksanakan pada semester ganjil tahun pelajaran 20109/ 2020.

Analisa data merupakan bagian yang amat penting dalam metode ilmiah, karena dengan analisalah data tersebut dapat diberi arti dan makna yang berguna dalam memecahkan masalah penelitian. Analisa adalah mengelompokkan, membuat suatu urutan, mengolah, serta menyingkatkan data sehingga mudah untuk dibaca. Mengingat data kualitatif yang dikumpulkan oleh penelitian ini berbentuk narasi dan bersifat deskripsi atas berbagai kejadian, interaksi, argumentasi, pernyataan sikap, dan perilaku subyek penelitian, maka teknik analisis data yang digunakan dalam penelitian ini adalah teknik deskriptif.

\section{HASIL DAN PEMBAHASAN}

Untuk setiap pertemuan penelitian dilakukan selama 70 menit. Pada pertemuan awal proses pembelajaran dimuali dengan pemanasan ringan berupa salam dan sapaan beserta balasannya. Karena memulai belajar dengan semangat dan sesuatu yang baru bagi murid adalah langkah awal yang sangat berpengaruh dalam kelanjutan proses belajar. Selanjutnya pelajaran dimulai dengan dengan melontarkan beberapa pertanyaan sebagai pemancing penyebutan judul dari pelajaran yang akan diajarkan. Dalam pembelajaran kali ini peneliti menggunakan variasi metode demonstrasi dengan cooperative learning untuk menarik minat siswa dalam mengikuti 
PTK, Vol.2 No.2 2022

ISSN: 2747-1977 (Print) / 2747-1969 (Online)

DOI: https://doi.org/10.53624/ptk.v2i2.58

pelajaran IPS. Peneliti berusaha menyajikan materi secara ringan dan menarik sehingga mudah untuk dipahami. Untuk menghindari rasa bosan selama proses belajar mengajar berlangsung sesekali saya mengajukan pertanyaan dan mengajak siswa berdiskusi dengan menggunakan alat peraga yang sudah disiapkan. Sejauh ini metode demonstrasi dan metode cooperative learning yang peneliti pergunakan dalam pembelajaran IPS mendapat respon yang cukup baik dari para siswa dan dapat memberikan motivasi serta peningkatan hasil belajar.

Seperti biasanya setiap pertemuan berlangsung selama 70 menit. Pada pertemuan kedua ini peneliti bersama dengan siswa membagi kelas dalam beberapa kelompok. Kemudian kami melakukan diskusi sederhana untuk menjelaskan tentang pentingnya memiliki semangat kerja. Yang selanjutnya untuk mengetahui sejauh mana keberhasilan siswa dalam memahami materi yang diajarkan, peneliti memberikan lembar kerja untuk dikerjakan secara berkelompok dan individu.

Kelas terbagi menjadi beberapa kelompok, tepatnya enam kelompok yang masing-masing terdiri dari 5 siswa dan salah satu kelompok terdiri dari 6 siswa, menyesuaikan dengan jumlah siswa satu kelas. Pada pertemuan kali ini siswa sudah mulai aktif dalam mengikuti diskusi kelompok sesuai dengan tema yang telah ditetapkan. Mereka juga aktif bertanya tentang materi yang belum dipahami. Selain itu peniliti juga memberikan tugas individu unruk mengetahui kemampuan siswa secara individual. Metode pembelajaran kooperatif tampaknya mampu memotivasi siswa.

Tabel 1. Hasil belajar siswa pada materi IPS Siklus 1 pertemuan pertama

\begin{tabular}{|c|c|c|c|c|c|c|c|}
\hline \multirow{2}{*}{ No. Urut } & \multirow{2}{*}{ Skor } & \multicolumn{2}{|c|}{ Keterangan } & \multirow{2}{*}{ No. Urut } & \multirow{2}{*}{ Skor } & \multicolumn{2}{|c|}{ Keterangan } \\
\hline & & $\mathrm{T}$ & TT & & & $\mathrm{T}$ & TT \\
\hline 1 & 80 & $\sqrt{ }$ & & 17 & 40 & & $\sqrt{ }$ \\
\hline 2 & 50 & & $\sqrt{ }$ & 18 & 70 & $\sqrt{ }$ & \\
\hline 3 & 80 & $\sqrt{ }$ & & 19 & 80 & $\sqrt{ }$ & \\
\hline 4 & 60 & & $\sqrt{ }$ & 20 & 70 & $\sqrt{ }$ & \\
\hline 5 & 40 & & $\sqrt{ }$ & 21 & 60 & & $\sqrt{ }$ \\
\hline 6 & 80 & $\sqrt{ }$ & & 22 & 70 & $\sqrt{ }$ & \\
\hline 7 & 70 & $\sqrt{ }$ & & 23 & 80 & $\sqrt{ }$ & \\
\hline 8 & 60 & & $\sqrt{ }$ & 24 & 60 & & $\sqrt{ }$ \\
\hline 9 & 70 & $\sqrt{ }$ & & 25 & 80 & $\sqrt{ }$ & \\
\hline 10 & 80 & $\sqrt{ }$ & & 26 & 60 & & $\sqrt{ }$ \\
\hline 11 & 60 & & $\sqrt{ }$ & 27 & 50 & & $\sqrt{ }$ \\
\hline 12 & 70 & $\sqrt{ }$ & & 28 & 80 & $\sqrt{ }$ & \\
\hline 13 & 80 & $\sqrt{ }$ & & 29 & 60 & & $\sqrt{ }$ \\
\hline 14 & 70 & $\sqrt{ }$ & & 30 & 80 & $\sqrt{ }$ & \\
\hline 15 & 40 & & $\sqrt{ }$ & 31 & 50 & & $\sqrt{ }$ \\
\hline 16 & 80 & $\sqrt{ }$ & & & & & \\
\hline Jumlah & 1070 & 10 & 6 & Jumlah & 990 & 8 & 7 \\
\hline & & $\begin{array}{r}\text { Juml } \\
\text { Rat }\end{array}$ & $\begin{array}{l}\text { lah } \\
\mathrm{Ma} \\
\mathrm{Sko}\end{array}$ & $\begin{array}{l}2060 \\
\text { aal Ideal } 31 \\
\text { capai } 66,4\end{array}$ & & & \\
\hline
\end{tabular}


Tabel 2. Rekapitulasi Hasil Tes Pada Siklus I

\begin{tabular}{clc}
\hline No & \multicolumn{1}{c}{ Uraian } & Hasil Siklus I \\
\hline 1 & Nilai rata-rata tes formatif & 66,45 \\
2 & Jumlah siswa yang tuntas belajar & 18 \\
3 & Persentase ketuntasan belajar & $58,06 \%$ \\
\hline
\end{tabular}

Table 3. Distribusi Nilai Tes Pada Siklus II

\begin{tabular}{|c|c|c|c|c|c|c|c|}
\hline \multirow{2}{*}{ No. Urut } & \multirow{2}{*}{ Skor } & \multicolumn{2}{|c|}{ Keterangan } & \multirow{2}{*}{ No. Urut } & \multirow{2}{*}{ Skor } & \multicolumn{2}{|c|}{ Keterangan } \\
\hline & & $\mathrm{T}$ & TT & & & $\mathrm{T}$ & TT \\
\hline 1 & 80 & $\sqrt{ }$ & & 17 & 70 & $\sqrt{ }$ & \\
\hline 2 & 70 & $\sqrt{ }$ & & 18 & 90 & $\sqrt{ }$ & \\
\hline 3 & 90 & $\sqrt{ }$ & & 19 & 80 & $\sqrt{ }$ & \\
\hline 4 & 90 & $\sqrt{ }$ & & 20 & 90 & $\sqrt{ }$ & \\
\hline 5 & 100 & $\sqrt{ }$ & & 21 & 60 & & $\sqrt{ }$ \\
\hline 6 & 80 & $\sqrt{ }$ & & 22 & 80 & $\sqrt{ }$ & \\
\hline 7 & 70 & $\sqrt{ }$ & & 23 & 100 & $\sqrt{ }$ & \\
\hline 8 & 60 & & $\sqrt{ }$ & 24 & 60 & & $\sqrt{ }$ \\
\hline 9 & 70 & $\sqrt{ }$ & & 25 & 90 & $\sqrt{ }$ & \\
\hline 10 & 100 & $\sqrt{ }$ & & 26 & 70 & $\sqrt{ }$ & \\
\hline 11 & 60 & & $\sqrt{ }$ & 27 & 100 & $\sqrt{ }$ & \\
\hline 12 & 70 & $\sqrt{ }$ & & 28 & 90 & $\sqrt{ }$ & \\
\hline 13 & 80 & $\sqrt{ }$ & & 29 & 70 & $\sqrt{ }$ & \\
\hline 14 & 70 & $\sqrt{ }$ & & 30 & 100 & $\sqrt{ }$ & \\
\hline 15 & 90 & $\sqrt{ }$ & & 31 & 70 & & $\sqrt{ }$ \\
\hline 16 & 100 & $\sqrt{ }$ & & & & & \\
\hline Jumlah & 1280 & 14 & 2 & Jumlah & 1220 & 12 & 3 \\
\hline & & $\begin{array}{r}\text { Jumlal } \\
\text { Rata }\end{array}$ & $\begin{array}{l}\text { lah } \\
\mathrm{Ma} \\
\mathrm{Sko}\end{array}$ & $\begin{array}{l}\text { r } 2500 \\
\text { mal Ideal } 3 \\
\text { ercapai } 80,\end{array}$ & & & \\
\hline
\end{tabular}

Tabel 4 Rekapitulasi Hasil Tes Pada Siklus II

\begin{tabular}{|c|l|c|}
\hline No & \multicolumn{1}{|c|}{ Uraian } & Hasil Siklus II \\
\hline 1 & Nilai rata-rata tes formatif & 80,64 \\
2 & Jumlah siswa yang tuntas belajar & 26 \\
3 & Persentase ketuntasan belajar & $83,87 \%$ \\
\hline
\end{tabular}

PTK: Jurnal Tindakan Kelas | Hal: 86-93 
PTK, Vol.2 No.2 2022

ISSN: 2747-1977 (Print) / 2747-1969 (Online)

DOI: https://doi.org/10.53624/ptk.v2i2.58

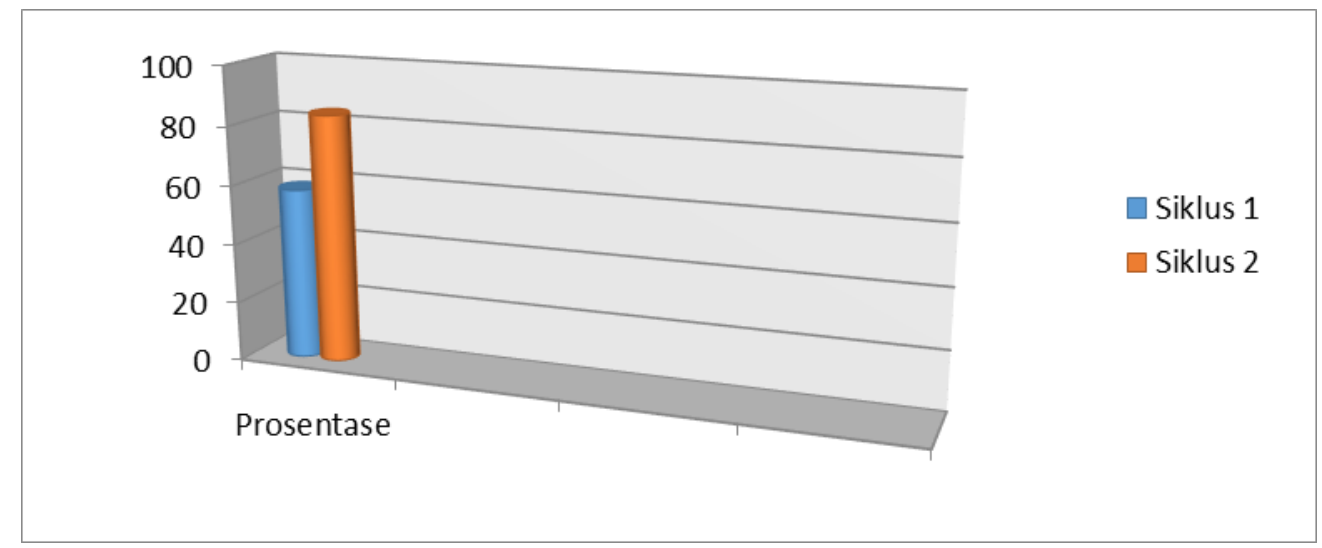

Gambar 2. Diagram Prosentase Ketutasan Hasil Belajar pada Siklus I dan II

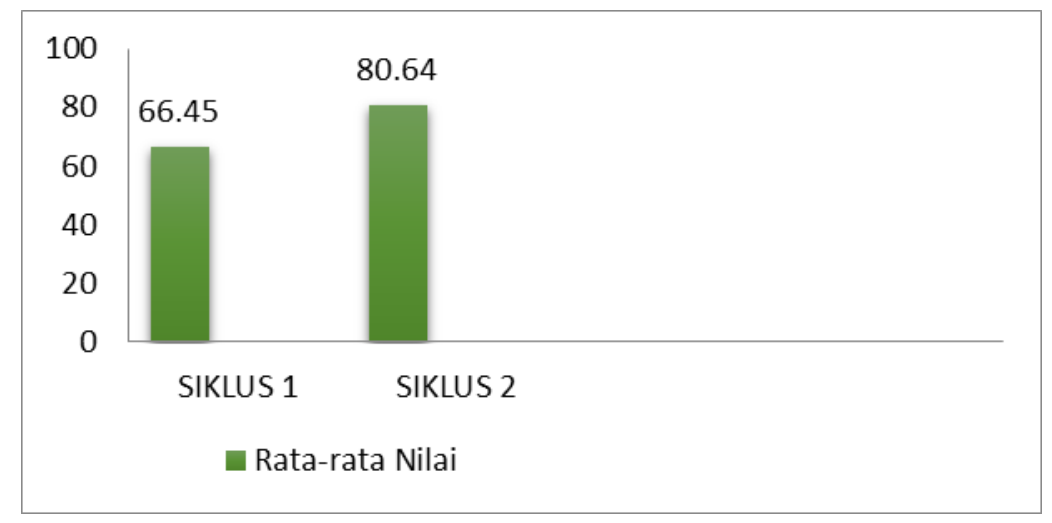

Gambar 3. Diagram Perolehan Rata-rata Nilai pada Siklus I dan II

\section{KESIMPULAN}

Dari hasil kegiatan pembelajaran yang telah dilakukan selama dua siklus, dan berdasarkan seluruh pembahasan serta analisis yang telah dilakukan dapat disimpulkan sebagai berikut: 1) Pembelajaran dengan metode cooperatif learning memiliki dampak positif dalam meningkatkan hasil belajar belajar siswa yang ditandai dengan peningkatan ketuntasan belajar siswa dalam setiap siklus, yaitu siklus I $(58,06 \%)$, dan siklus II $(83,87 \%)$. 2) Penerapan metode cooperatif learning mempunyai pengaruh positif, yaitu dapat meningkatkan motivasi, keaktifa, antusias, serta kekompakan belajar siswa yang ditunjukan dengan rata-rata jawaban siswa hasil 
wawancara yang menyatakan bahwa siswa tertarik dan berminat dengan metode cooperatif learning sehingga mereka menjadi termotivasi untuk belajar.

\section{DAFTAR PUSTAKA}

Hamalik, O. 2001. Proses Belajar Mengajar. Jakarta : PT Bumi Aksara

Dr.I.G.A.K Wardani( 2004 ) Penelitian Tindakan Kelas, Universitas Terbuka Chapman \& Hall Inc.

Marsono, A. J. 1995. Media Pembinaan Pendidikan, Fa Dian Indah Pustaka, Surabaya.

Nasution, S. 1992. Metode Penelitian Naturalistik Kualitatif Tarsito, Bandung.

Ngatemi, 1992. Media Pembinaan Pendidikan, Fa Dian lndah Pustaka, Surabaya

Surabaya. Undang - undang No.20, 2003. Sistem Pendidikan Nasional, Depdiknas, Jakarta. 